\title{
MICROLITHIASIS OF THE GALLBLADDER: ROLE OF ENDOSCOPIC ULTRASONOGRAPHY IN PATIENTS WITH IDIOPATHIC ACUTE PANCREATITIS
}

José Celso Ardengh ${ }^{1 *}$, Carlos Alberto Malheiros ${ }^{2}$, Fares Rahal ${ }^{3}$, Victor Pereira ${ }^{3}$, Arnaldo José Ganc ${ }^{4}$

Trabalho realizado no Setor de Endoscopia e Ecoendoscopia do Hospital 9 de Julho, São Paulo, SP

*Correspondência:

Alameda dos Arapanés, $\mathrm{n}^{\circ} 881$ - cj 111 - Moema São Paulo - SP

CEP: 04524-001

Telefone: (11) 9688-6312

jcelso@uol.com.br

\begin{abstract}
SUMMARY
OBJEctives. Causes may be found in most cases of acute pancreatitis, however no etiology is found by clinical, biological and imaging investigations in 30\% of these cases. Our objective was to evaluate results from endoscopic ultrasonography (EUS) for diagnosis of gallbladder microlithiasis in patients with unexplained (idiopathic) acute pancreatitis.

MEtHods. Thirty-six consecutive non-alcoholic patients with diagnoses of acute pancreatitis were studied over a five-year period. None of them showed signs of gallstones on transabdominal ultrasound or tomography. We performed EUS within one week of diagnosing acute pancreatitis. Diagnosis of gallbladder microlithiasis on EUS was based upon findings of hyperechoic signals of 0.5-3.0 mm, with or without acoustic shadowing. All patients (36 cases) underwent cholecystectomy, in accordance with indication from the attending physician or based upon EUS diagnosis.

Results. Twenty-seven patients (75\%) had microlithiasis confirmed by histology and nine did not (25\%). EUS findings were positive in twenty-five. Two patients had acute cholecystitis diagnosed at EUS that was confirmed by surgical and histological findings. In two patients, EUS showed cholesterolosis and pathological analysis disclosed stones not detected by EUS. EUS diagnosed microlithiasis in four cases not confirmed by surgical treatment. In our study, sensitivity, specificity and positive and negative predictive values to identify gallbladder microlithiasis (with 95\% confidence interval) were 92.6\% (74.2-98.7\%), 55.6\% (22.7-84.7\%), 86.2\% (67.4-95.5\%) and 71.4\% (30.3-94.9\%), respectively. Overall EUS accuracy was $83.2 \%$.

ConcLusions. EUS is a very reliable procedure to diagnose gallbladder microlithiasis and should be used for the management of patients with unexplained acute pancreatitis. This procedure should be part of advanced endoscopic evaluation.
\end{abstract}

KEY wORDS: Gallstones. Endosonography. Pancreatitis. Diagnosis.

\section{INTRODUCTION}

It is usually not difficult to determine the cause of an episode of acute pancreatitis ${ }^{1}$. Excessive alcohol consumption and gallstone disease are responsible in most cases, and presence of these conditions can be established by the patient's history (alcohol abuse) and transabdominal ultrasound (gallstone disease) ${ }^{2}$.

Definition of microlithiasis is a matter of controversy. Definitions that have been used include radiological invisibility ${ }^{3,4}$, stones less than $5 \mathrm{~mm}$ in diameter ${ }^{5}$ and/or stones less than $3 \mathrm{~mm}$ in diameter ${ }^{6}$. Because of their small size, they may be difficult to detect and, when roentgenographically invisible, may constitute a diagnostic challenge in patients with recurrent acute pancreatitis ${ }^{5,6}$. Microlithiasis of the gallbladder is also dreaded for its tendency to migrate and cause acute pancreatitis. Indeed, gallbladder microlithiasis and microcholedocolithiasis are frequently found after surgical procedures and gallstones are found in the feces of $90 \%$ of patients with acute pancreatitis $4,7,8$.

The aim of this study was to evaluate the usefulness of endoscopic ultrasonography (EUS) for diagnosis of gallbladder microlithiasis. Thus, we determined sensitivity, specificity and predictive values of this method for recognition of gallbladder

\footnotetext{
1. Livre-Docente do Departamento de Anatomia e Cirurgia da Faculdade de Medicina de Ribeirão Preto da Universidade de São Paulo - FMRP/USP; Médico do Setor de Endoscopia do Hospital 9 de Julho e Médico da Secção de Endoscopia da Disciplina de Anatomia e Cirurgia do Hospital das Clínicas da Faculdade de Medicina de Ribeirão Preto da Universidade de São Paulo- HCFMRP-USP, São Paulo, SP

2. Chefe da área V (Estômago e Duodeno) da Faculdade de Ciências Médicas da Santa Casa de São Paulo, São Paulo, SP

3. Médico da área V ( Cirurgia de Estômago e Duodeno) da Faculdade de Medicina da Santa Casa de São Paulo, São Paulo, SP

4. Livre-Docente em Gastroenterologia e Médico do Setor de Endoscopia do Hospital Israelita Albert Einstein , São Paulo, SP
} 
microlithiasis especially in patients with unexplained acute pancreatitis and compared EUS findings of microlithiasis with its identification through surgical procedures.

\section{Methods}

\section{Patients with acute pancreatitis}

Sixty-six patients with acute pancreatitis, without etiological diagnosis were consecutively examined over a five-year period. Diagnosis of unexplained acute pancreatitis was made when the patient presented acute abdominal pain without any history of trauma, infection or use of medications (especially steroids, diuretics or antineoplastic agents), in addition to transabdominal ultrasound and computed tomography (CT) scans showing evidence of pancreatic inflammation. Ultrasound and CT showed absence of gallstones in all patients. The calcium and serum triglyceride levels $(<300$ $\mathrm{mg} / \mathrm{dl}$ ) were normal. Excessive alcohol consumption (more than $30 \mathrm{~g} /$ day) was ruled out for all these patients, due to their clinical histories ${ }^{9}$. We recorded the serum levels of amylase and lipase, main clinical signs and symptoms, EUS findings as well as those of microlithiasis in the gallbladder as reported by the surgeon.

\section{Exclusion criteria}

Five patients were excluded from this study because they did not undergo cholecystectomy. Twenty-five were also excluded since they presented stones greater than $3 \mathrm{~mm}$ in diameter; chronic pancreatitis; neoplasia; other causes for their episodes of acute pancreatitis that were identified by EUS; suspicious sludge during the immediate postoperative period; pregnancy; stenosis or chronic obstruction of biliary ducts; prolonged parenteral nutrition; liver cirrhosis; hemolysis; prolonged fasting ( $>2$ weeks); obesity with rapid weight loss; and oral contraceptive use $\mathrm{u}^{10,11}$.

\section{Study group}

Of the 36 patients fulfilling the above criteria, 23 (63.9\%) had had at least one episode of acute pancreatitis prior to the current attack (overall, 69 episodes in 36 patients), while thirteen $(36.1 \%$ ) presented acute pancreatitis for the first time. Transabdominal ultrasound and CT scans of the gallbladder did not disclose any abnormality, however CT scans showed evidence of pancreatitis in all patients (36). There were 21 women (58.4\%) and 15 men (41.6\%) with a mean age of 47.1 years (range 20 - 83 years).

All patients underwent EUS during the first week following diagnoses of acute pancreatitis. The EUS examinations were conducted by the same experienced endoscopist (JCA) using the commercially available Olympus GIF-UM30(Olympus America Inc., Melville, NY, USA) radial scanning system at 7.5 and 12 $\mathrm{MHz}$ and Pentax FG-38UX (Pentax Precision Instruments, Orangeburg, NY, USA), coupled to the HITACHI EUB 405(Mitsubishi, Conshockon, PA, USA) linear array scanning system at 5.0 and $7.5 \mathrm{MHz}$. During examinations, the patients were in prone position or left lateral decubitus.

Patients underwent topical anesthesia of the posterior pharynx and intravenous conscious sedation. The echoendoscope was advanced to the second portion of the duodenum, where the ampulla of Vater was identified and imaging was begun. Images of the infundibulum and body of the gallbladder were taken from the duodenum while images of the fundus were taken from the antrum.

Gallbladder microlithiasis was diagnosed using EUS when we found a hyperechoic signal $(0.5-3.0 \mathrm{~mm})$ with or without acoustic shadowing. Hyperechoic signals of more than 3.0 millimeters were excluded from this study. Thereafter, all patients underwent cholecystectomy, which was retrospectively reviewed. Findings from the surgical and/or histopathological data were compared with the EUS findings.

\section{Expression of the results and statistical analyses}

Statistical analysis was undertaken to obtain the sensitivity, specificity and negative and positive predictive values with $95 \%$ confidence intervals, and accuracy of the diagnosis of gallbladder microlithiasis by EUS. The sensitivity was defined as the ratio of patients with positive presence of microlithiasis by EUS examination in relation to patients with proven stones following surgical procedure. The specificity was defined as the ratio of patients with no biliary stones in relation to negative presence of microlithiasis by EUS examination. The negative and positive predictive values of the EUS examination for diagnosis of microlithiasis were obtained from the same group. This study was approved by the Research Ethics Boards of Hospital 9 de Julho and written informed consent was obtained from all patients

\section{Results}

\section{Patients}

The male-to-female ratio among the 36 patients was 1.4:1.0. Among these 36 patients with unexplained acute pancreatitis, abdominal pain was found in $100 \%$, vomiting in $86.1 \%$, jaundice in $12.1 \%$, pleural effusion in $11.1 \%$ and ascites in $11.1 \%$. The mean level of serum amylase was $780.4 \mathrm{UI} / \mathrm{I}$ (range 135 - $2557 \mathrm{UI} / \mathrm{I})$ and the mean level of serum lipase was 3428.5 UI/I (339 - $11.637 \mathrm{UI} / \mathrm{I})$.

\section{Endoscopic ultrasonography}

We performed 40 echoendoscopic examinations (twice in four patients). Among the 36 patients who underwent echoendoscopic examination, 3/36 (8.3\%) did not present any abnormality in the gallbladder, while the others did (33/36; $91.7 \%)$. The EUS identified presence of gallbladder microlithiasis (Figure 1 ) in 29/36 (80.6\%), acute cholecystitis (2) and cholesterolosis (2). We found four false positive cases and two false negatives in this sample of patients.

\section{EUS and surgical findings}

Multiple micro-gallstones were found in 27/36 (75\%) of the patients (Figures 1 and 2), while they were absent in 9/36 (25\%).

\section{Statistical analysis}

The sensitivity, specificity, negative and positive predictive values, accuracy and $95 \%$ confidence intervals of the EUS for the investigation of gallbladder microlithiasis are in Table 1. 


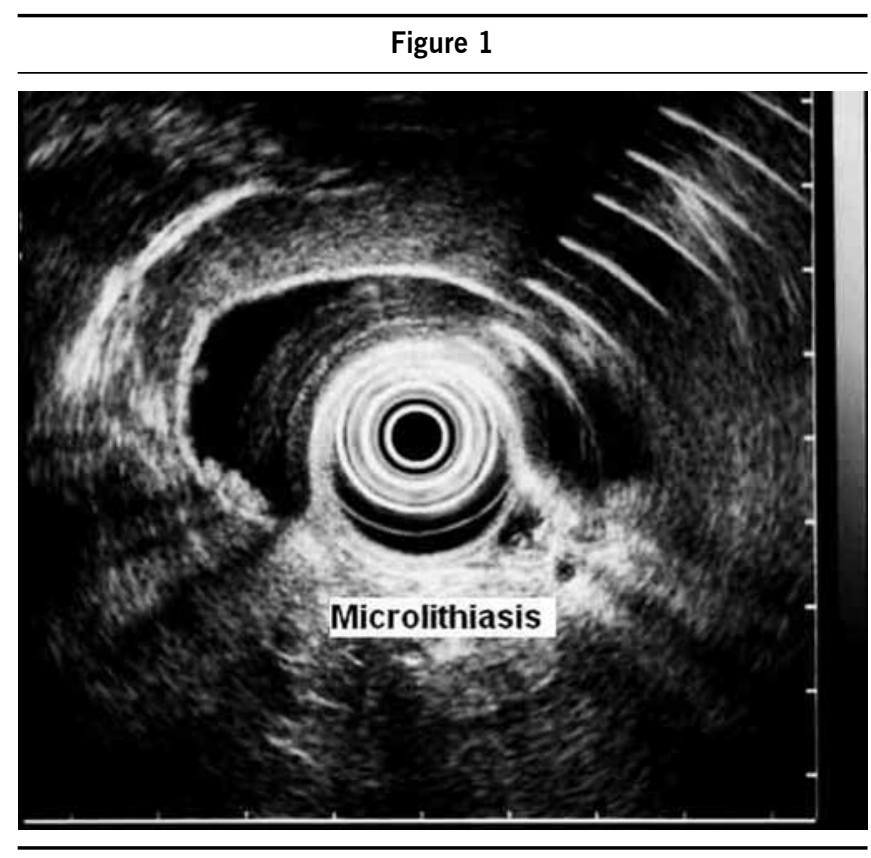

Table 1. Statistical values from EUS to identify gallbladder microlithiasis, in relation to findings from the surgical piece specimens of the 36 patients.

\begin{tabular}{lcc}
\hline & $\%$ & Confidence interval (\%) \\
Sensitivity & 92.6 & $74.2-98.7$ \\
Specificity & 55.6 & $22.7-84.7$ \\
Positive predictive value & 86.2 & $67.4-95.5$ \\
Negative predictive value & 71.4 & $30.3-94.9$ \\
Accuracy & 83.2 & $66.5-93.0$ \\
\hline
\end{tabular}

\section{Discussion}

Diagnosis of acute pancreatitis is clinically and biochemically established. The main symptoms are abdominal pain and vomiting. Hyperamylasemia is considered an essential sign of acute pancreatitis, occurring in up to $80 \%$ of cases. Lipase serum levels are elevated in the great majority of these patients, and levels remain high for a longer period than the amylase levels ${ }^{12}$. All these parameters were found in our series.

After systematic diagnostic investigation (clinical, biochemical and imaging methods) to identify an etiological agent for acute pancreatitis, $10 \%$ to $30 \%$ of the patients do not present any defined cause and are labeled cases of acute pancreatitis without apparent cause ${ }^{2,13}$.

Among the acute pancreatitis patients without a defined cause, $20 \%$ to $50 \%$ present microcalculi and tend to have recurrences with high morbidity-mortality rates ${ }^{8,14-17}$. Therefore, it is important to identify microcalculi, because of possible recurrent relapses of acute pancreatitis and to enable early treatment

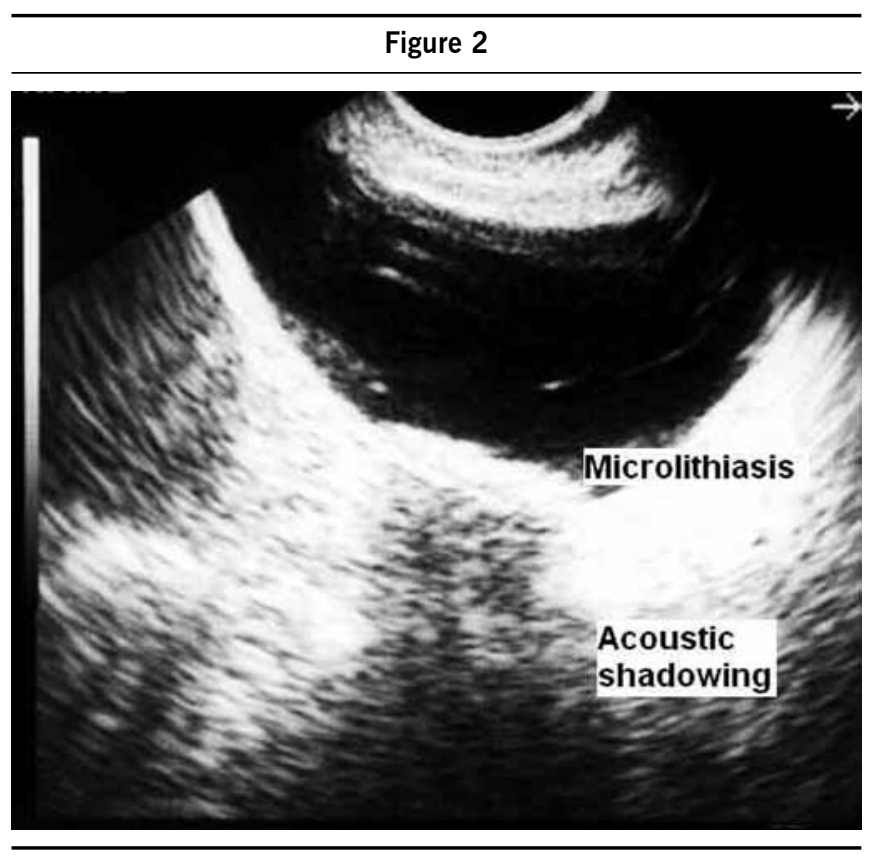

that would avoid such relapses ${ }^{6,13-17}$. For this reason attention has been directed to introduce sensitive noninvasive diagnostic methods and revive certain old methods (bile collection for crystal investigation) ${ }^{18}$.

Thus, advanced endoscopic techniques such as endoscopic retrograde cholangiopancreatography $(\mathrm{ERCP})^{1,19,20}$, ERCP with bile collection for investigating microcrystals ${ }^{18,21}$ and EUS for the purpose of detecting microlithiasis have progressed in the propaedeutics for this disease ${ }^{22-25}$.

Patients with radiolucent migrating calculi present episodes of bile colics, recurrent acute pancreatitis and transitory jaundice, despite the radiological normal appearance of the bile ducts, as seen using ERCP and transabdominal ultrasound ${ }^{4}$. According to some authors, microcalculi are frequently radiolucent ${ }^{3,4}$.

We considered bile sludge (Figure 2) to represent microlithiasis, since this sludge and calculi with more than $4 \mathrm{~mm}$ diameter can be identified on transabdominal ultrasound because they present an acoustic shadow ${ }^{26}$. Presence of microcalculi was also shown in $8.3 \%$ of patients with bile sludge who underwent surgery ${ }^{27}$. It can be concluded that presence of bile sludge should be considered abnormal, since there may be precipitates of calcium bilirubinate or cholesterol (microcalculi) ${ }^{28}$. In this series, three cases presented with appearance of bile sludge on EUS, and surgical findings revealed the presence of microcalculi.

Using US or radiographic methods, for calculi sizes of less than or equal to $3 \mathrm{~mm}$ in diameter, the diagnosis rate is around $25 \%{ }^{6,7}$. If the calculi range between 3 and $5 \mathrm{~mm}$ in diameter, the rate is $40 \%{ }^{5}$ and, if the radiolucency criterion is used, the rate falls to $10 \%$. For this reason, calculi less than or equal to 3 $\mathrm{mm}$ in diameter are a diagnostic challenge, particularly because of confusion with bile sludge $26-28$.

Patients with recurrent acute pancreatitis, whose transabdominal ultrasound and ERCP are normal may present calculi during the operation ${ }^{29}$. Calculi size and density are the factors 
responsible for the false results ${ }^{29}$. Other risk factors for acute pancreatitis relate to the number of calculi, width of the cystic duct and width and length of the Oddi sphincter ${ }^{30,31}$.

Transabdominal ultrasound is the examination of choice to diagnose biliary diseases ${ }^{6,29,32}$. Especially since transabdominal ultrasound presents high sensitivity for diagnosis of biliary calculi33, 34. However, during episodes of acute pancreatitis, sensitivity is lower, ranging from 58 to $67 \%{ }^{35,36}$.

In some cases of acute pancreatitis without apparent cause, ERCP may identify potentially treatable conditions. This may occur in 30 to $50 \%$ of cases $^{37}$ and those presenting calculi between 5 and $15 \%{ }^{29}, 37$. However, amylase levels may be elevated in 30 to $75 \%$ of asymptomatic patients ${ }^{38}$.

Bile collection to investigate biliary crystals in comparison with EUS, in patients with normal transabdominal ultrasound and a diagnosis confirmed by surgery, showed sensitivity, specificity, positive predictive value and negative predictive value for EUS of $96 \%, 86 \%, 89 \%$ and $95 \%$ and for bile collection of $67 \%, 91 \%, 89 \%$ and $70 \%$, respectively ${ }^{39}$. False positive results occurred due to acoustic reverberation caused by movement of the bladder wall, thereby forming artifacts that were confounded with microcalculi ${ }^{39}$.

In the present study, endoscopic examination was shown to be advantageous in relation to transabdominal ultrasound because it enabled adequate examination of the gallbladder during the acute pancreatitis episodes. It is also more advantageous than bile collection, because it does not use cholecystokinetic agents to obtain bile, which could, at least hypothetically, cause recurrence or worsening of the pancreatitis $^{40}$. It is also less invasive than ERCP ${ }^{41}$ and does not worsen the condition of acute pancreatitis ${ }^{42}$

Based upon sensitivity (92.6\%), positive predictive $(86.2 \%)$ and accuracy $(83.2 \%)$ values with their respective confidence intervals $(74.2-98.7 \%, 67.4-95.5 \%$ and 63.5$93 \%$ ) that were obtained (Table 1), it can be inferred that EUS is safe and provides high-precision diagnosis. Presumably responsible factors for this high detection rate are: 1) the gallbladder is closely related to the stomach and duodenal wall; 2) the median distance between the echoendoscopic transducer and the gallbladder is small $(0.5 \mathrm{~mm}) ; 3)$ the focal point is easily found, thereby making it possible to obtain images without great distortions; 4) the whole gallbladder (infundibulum, body and fundus) and cystic duct are examined, even under severe conditions of pancreatitis; and 5) the use of frequencies of 5.0, 7.5 and $12 \mathrm{MHz}$ intensifies details in the images.

Previous studies using EUS to diagnose microlithiasis found sensitivity rates of $95 \%$ to $97 \% 39,41,43$, with a positive predictive value of $100 \%{ }^{43}$.

In our study, the specificity and negative predictive value (with their 95\% confidence intervals) were 55.6\% (22.7-84.7\%) and $71.4 \%$ (30.3-94.9\%), respectively. These estimates, with their respective confidence intervals, are questionable and imprecise, considering that in other studies, the specificity ranged from $76 \%$ to $86 \% 39,41$. Perhaps these results occurred because of the small sample of individuals without the disease and the great possibility that the patients examined here would have gallbladder etiology as the cause of their episodes of acute pancreatitis.
It is emphasized that, despite being an invasive technique, EUS does not present: 1) difficulties involved in catheterizing the papilla; 2) inconvenience of injecting contrast to make the biliary-pancreatic duct visible; 3) problems with the technique of bile collection from the bile duct and gallbladder, in which stimulation using cholecystokinetic agents is required to obtain the material; and 4) complications involved in gallbladder puncture to obtain bile. Thus, EUS examination seems to be harmless and have a reasonable degree of safety to identify microcalculi of the gallbladder without worsening or triggering relapses of acute pancreatitis. It is noteworthy that the proportion of pancreatitis cases labeled as not having any apparent cause presents an inverse relationship with the quality of diagnostic methods used.

We believe that we have clearly and precisely demonstrated that EUS represents an important advance, since it reveals gallbladder microlithiasis in a significant proportion of cases of acute pancreatitis, initially labeled as not having any apparent cause. This examination is practical, safe, objective and easy to perform. From the sensitivity obtained with this patient sample, early and appropriate therapeutic interventions are possible, which seems to notably reduce risk of recurrences ${ }^{15,44}$.

In the present series, EUS was fundamentally and clearly superior to transabdominal ultrasound for identifying microcalculi of the gallbladder that were associated with relapses of acute pancreatitis without apparent cause. Likewise, in comparison with data from investigating crystals in bile using various techniques reported in literature (ERCP), results from EUS were at least similar, without inconveniences of the ERCP method, and were safer presenting notably greater sensitivity22, ${ }^{41}$. Nevertheless, it must be stressed that, to obtain satisfactory conclusions regarding the two techniques, comparative studies with a rigorous methodology are required. This would make it possible to ascertain which method would be best for patients presenting acute pancreatitis without apparent cause.

\section{ConcLusion}

EUS is very reliable for diagnosing gallbladder microlithiasis and should be used for managing patients with unexplained acute pancreatitis. This procedure should be part of advanced endoscopic evaluation.

\section{Conflict of interest: none}

\section{Resumo}

MICROCOLECISTOLITÍASE: PAPEL DA ECOENDOSCOPIA EM PACIENTES COM PANCREATITE AGUDA SEM CAUSA APARENTE

Objetivos. Cerca de $30 \%$ dos doentes com PA rotulada como sem causa aparente apresentam colecistomicrolitíase (cálculos com até $3 \mathrm{~mm}$ ). Não há, no momento, consenso quanto ao melhor método propedêutico para diagnosticá-lo e, entre os propostos, nenhum apresenta alta sensibilidade. A ecoendoscopia (EE) é excelente no diagnóstico da pancreatite crônica incipiente e microcálculos da vesícula biliar (MCV) ou colédoco. São poucas as referências na literatura internacional e nenhuma na nacional a respeito do emprego da EE na PA. O objetivo deste trabalho é o de estabelecer o valor da EE no diagnóstico da colecistomicrolitíase em doentes com PA sem causa aparente. 
Métodos. Trinta e seis pacientes com o diagnóstico de PA sem causa aparente foram consecutivamente estudados durante cinco anos. Dos enviados para exame ecoendoscópico, 21 mulheres e 15 homens com média de idade de 41,6 anos. Todos haviam sido submetidos antes a pelo menos um US e uma TC, que não revelaram alterações na via bílio-pancreática e 63,9\% deles tinham apresentado mais de um episódio de $P A$. O diagnóstico da colecistomicrolitíase pela EE realizada até uma semana durante o surto de PA baseou-se no tamanho do cálculo (até $3 \mathrm{~mm}$, inclusive) e hiperecogeneicidade com ou sem sombra acústica. Todos os doentes foram colecistectomizados, após o exame ecoendoscópico.

Resultado. O exame das peças cirúrgicas mostrou que 27 (75\%) doentes apresentavam MCV e nove (25\%) não. A EE levou a erro no diagnóstico da microlitíase em seis (16,8\%) casos, quatro casos de falsos-positivos e dois casos de falsosnegativos. Em 30 casos (83,2\%) houve confirmação dos seus resultados. A sensibilidade, a especificidade, os valores preditivos positivo, negativo e a acurácia (com intervalo de confiança de 95\%) para a EE no diagnóstico dos MCV foram: 92,6\% (74,2 a 98,7\%), 55,6\% (22,7 a 84,7\%), 86,2\% (67,4\% a $95,5 \%), 71,4 \%$ (30,3 a $94,9 \%)$ e $83,2 \%(66,5 \%$ a $93 \%)$ respectivamente.

Conclusão. A EE mostra-se, portanto, de grande valor na identificação da colecistomicrolitíase e a PA não deve ser considerada sem causa aparente antes da realização desse exame. [Rev Assoc Med Bras 2010; 56(1): 27-31]

Unitermos: Cálculos Biliares.Endossonografia.Pancreatite.Diagnóstico.

\section{REFERENCES}

1. Al-Haddad M, Wallace MB. Diagnostic approach to patients with acute idiopathic and recurrent pancreatitis, what should be done? World J Gastroenterol. 2008;14(7):1007-10.

2. van Brummelen SE, Venneman NG, van Erpecum KJ, VanBerge-Henegouwen GP. Acute idiopathic pancreatitis: does it really exist or is it a myth? Scand J Gastroenterol. 2003(239):117-22.

3. Pfefferman R, Luttwak EM. Gallstone pancreatitis. Exploration of the biliary system in pancreatitis of undetermined origin. Arch Surg. 1971;103(4):484-6.

4. Dayan L, Cherif-Zahar K, Lepage B, Bories-Azeau A. [Diagnostic traps and proceduretofollow in radio-invisible biliarycalculi]. J Chir(Paris). 1976;111(4):431-42.

5. Goinard P, Pelissier G. [Biliary micro-lithiasis.]. Presse Med 1962;70:260-1.

6. Houssin D, Castaing D, Lemoine J, Bismuth H. Microlithiasis of the gallbladder. Surg Gynecol Obstet. 1983;157(1):20-4.

7. Bertrand L, Lamarque JL. [Biliary microlithiasis. Medico-radiological observations]. Nouv Presse Med .1975;4(44):3135-8.

8. Dill JE, Dill BP. Microlithiasis and pancreatitis. Gastrointest Endosc. 2002;56(5):784; author reply 784-5.

9. Acosta JM, Ledesma CL. Gallstone migration as a cause of acute pancreatitis. N Engl J Med. 1974;290(9):484-7.

10. Ohara N, Schaefer J. Clinical significance of biliary sludge. J Clin Gastroenterol. 1990;12(3):291-4.

11. Strasberg SM, Toth JL, Gallinger S, Harvey PR. High protein and total lipid concentration are associated with reduced metastability of bile in an early stage of cholesterol gallstone formation. Gastroenterology. 1990;98(3):739-46.

12. Frossard JL, Steer ML, Pastor CM. Acute pancreatitis. Lancet. 2008;371(9607):143-52.

13. Tarnasky PR, Hawes RH. Endoscopic diagnosis and therapy of unexplained (idiopathic) acute pancreatitis. Gastrointest Endosc Clin North Am. 1998;8(1):13-37.

14. Lee SP, Nicholls JF. Nature and composition of biliary sludge. Gastroenterology. 1986;90(3):677-86

15. Ros E, Navarro S, Bru C, Garcia-Puges A, Valderrama R. Occult microlithiasis in idiopathic acute pancreatitis: prevention of relapses by cholecystectomy or ursodeoxycholic acid therapy. Gastroenterology. 1991;101(6):1701-9.

16. Liu CL, Lo CM, Chan JK, Poon RT, Fan ST. EUS for detection of occult cholelithiasis in patients with idiopathic pancreatitis. Gastrointest Endosc. 2000;51(1):28-32.
17. Levy MJ. The hunt for microlithiasis in idiopathic acute recurrent pancreatitis: should we abandon the search or intensify our efforts? Gastrointest Endosc. 2002;55(2):286-93.

18. Chebli JM, Ferrari Junior AP, Silva MR, Borges DR, Atallah AN, das Neves MM. [Biliary microcrystals in idiopathic acute pancreatitis: clue for occult underlying biliary etiology]. Arq Gastroenterol. 2000;37(2):93-101.

19. DiMagno MJ, DiMagno EP. New advances in acute pancreatitis. Curr Opin Gastroenterol. 2007;23(5):494-501.

20. Garg PK, Tandon RK, Madan K. Is biliary microlithiasis a significant cause of idiopathic recurrent acute pancreatitis? A long-term follow-up study. Clin Gastroenterol Hepatol. 2007;5(1):75-9.

21. Buscail L, Escourrou J, Delvaux M, Guimbaud R, Nicolet T, Frexinos J, et al. Microscopic examination of bile directly collected during endoscopic cannulation of the papilla. Utility in patients with suspected microlithiasis. Dig Dis Sci. 1992;37(1):116-20.

22. Tandon M, Topazian M. Endoscopic ultrasound in idiopathic acute pancreatitis. Am J Gastroenterol. 2001;96(3):705-9.

23. Pellicano R, Repici A, Goss M, Carucci P, Rocca R, Bruno M, et al. Role of endoscopic ultrasound in biliary and unexplained pancreatitis. Minerva Med. 2007;98(4):361-5.

24. Vila JJ, Borda F, Jimenez FJ. [The role of endoscopic ultrasonography in the etiological evaluation of idiopathic acute pancreatitis]. Rev Esp Enferm Dig. 2008;100(2):90-7.

25. Petrone MC, Arcidiacono PG, TestoniPA. Endoscopicultrasonography for evaluating patients with recurrent pancreatitis. World J Gastroenterol. 2008;14(7): 1016-22.

26. Good LI, Edell SL, Soloway RD, Trotman BW, Mulhern C, Arger PA. Ultrasonic properties of gallstones. Effect of stone size and composition. Gastroenterology. 1979;77(2):258-63.

27. Simeone JF, Mueller PR, Ferruci JT Jr, Harbin WP, Wittenberg J. Significance of nonshadowing focal opacities at cholecystosonography. Radiology. 1980;137(1 Pt 1):181-5.

28. Filly RA, Allen B, Minton MJ, Bernhoft R, Way LW. In vitro investigation of the origin of echoes with biliary sludge. J Clin Ultrasound. 1980;8(3):193-200.

29. Venu RP, Geenen JE, Toouli J, Stewart E, Hogan WJ. Endoscopic retrograde cholangiopancreatography. Diagnosis of cholelithiasis in patients with normal gallbladder x-ray and ultrasound studies. JAMA. 1983;249(6):758-61.

30. Barraya L, Pujol Soler R, Yvergneaux JP. [The region of Oddis sphincter: millimetric anatomy]. Presse Med. 1971;79(55):2527-34.

31. Armstrong CP, Taylor TV, Jeacock J, Lucas S. The biliary tract in patients with acute gallstone pancreatitis. Br J Surg. 1985;72(7):551-5.

32. Humbert P, Casals A, Boix J, Planas R, Morillas R, Barranco C, et al. [Usefulness of microscopic study of the duodenal bile in the diagnosis of pancreatitis of unknown cause]. Rev Esp Enferm Apar Dig. 1989;75(5):471-4.

33. Cotton PB, Beales JS. Endoscopic pancreatography in management of relapsing acute pancreatitis. Br Med J. 1974;1(5908):608-11.

34. Cooperberg PL, Gibney RG. Imaging of the gallbladder, 1987. Radiology. 1987;163(3):605-13.

35. Neoptolemos JP, Davidson BR, Winder AF, Vallance D. Role of duodenal bile crystal analysis in the investigation of idiopathic pancreatitis. Br J Surg. 1988;75(5):450-3.

36. Bolognese A, Muttillo IA, Scopinaro F, Banci M, Amadori LM, De Martino F, et al. [Biliary scintigraphy vs. ultrasonography in the etiological diagnosis of acute pancreatitis]. J Chir (Paris). 1996;133(2):78-81.

37. Feller ER. Endoscopic retrograde cholangiopancreatography in the diagnosis of unexplained pancreatitis. Arch Intern Med. 1984;144(9):1797-9.

38. Aliperti G. Complications related to diagnostic and therapeutic endoscopic retrograde cholangiopancreatography. Gastrointest Endosc Clin North Am. 1996;6(2):379-407.

39. Dahan P, Andant C, Levy P, Amouyal P, Amouyal G, Dumont M, et al. Prospective evaluation of endoscopic ultrasonography and microscopic examination of duodenal bile in the diagnosis of cholecystolithiasis in 45 patients with normal conventional ultrasonography. Gut. 1996;38(2):277-81.

40. Reisberg IR, Mabee GW. Endoscopic biliary drainage for detection of gallbladder disease. Gastrointest Endosc. 1979;25(1):6-9.

41. Lachter J, Rubin A, Shiller M, Lavy A, Yasin K, Suissa A, et al. Linear EUS for bile duct stones. Gastrointest Endosc. 2000;51(1):51-4.

42. Blackwood WD, Vennes JA, Silvis SE. Post-endoscopy pancreatitis and hyperamylasuria. Gastrointest Endosc. 1973;20(2):56-8.

43. Dill JE, Hill S, Callis J, Berkhouse L, Evans P, Martin D, et al. Combined endoscopic ultrasound and stimulated biliary drainage in cholecystitis and microlithiasis-diagnoses and outcomes. Endoscopy. 1995;27(6):424-7.

44. Chebli JM, Duarte Gaburri P, Meirelles de Souza AF, de Castro Ferreira LE, Andrade Chebli L, Ferrari AP Jr, et al. "Idiopathic" acute pancreatitis due to biliary sludge: prevention of relapses by endoscopic biliary sphincterotomy in high-risk patients. Am J Gastroenterol. 2000;95(10):3008-9.

Artigo recebido: 20/12/08

Aceito para publicação: 03/06/09 